\title{
Cost-efficient one-part alkali-activated mortars with low global warming potential for floor heating systems applications
}

\author{
Z. Abdollahnejad, S. Miraldo, F. Pacheco-Torgal* and J. Barroso Aguiar \\ C-TAC, University of Minho, Guimarães, Portugal
}

(Received 4 June 2015; accepted 24 November 2015)

\begin{abstract}
Increasing building energy efficiency is one the most cost-effective ways to reduce emissions. The use of thermal insulation materials mitigates heat loss in buildings, therefore minimising heat energy needs. In recent years, several papers were published on the subject of foam alkali-activated cements with enhanced thermal conductivity. However, on those papers cost analysis was strangely avoided. This paper presents experimental results on one-part alkali-activated cements. It also includes global warming potential assessment and cost analysis. Foam one-part alkali-activated cements cost simulations considering two carbon dioxide social costs scenarios are also included. The results show that one-part alkali-activated cements mixtures based on $26 \% \mathrm{OPC}+58.3 \% \mathrm{FA}+8 \% \mathrm{CS}+7.7 \% \mathrm{CH}$ and $3.5 \%$ hydrogen peroxide constitute a promising cost-efficient $\left(67 \mathrm{euro} / \mathrm{m}^{3}\right)$, thermal insulation solution for floor heating systems. This mixture presents a low global warming potential of $443 \mathrm{KgCO}_{2 \mathrm{eq}} / \mathrm{m}^{3}$. The results confirm that in both carbon dioxide social cost scenarios the mixture $26 \mathrm{OPC}+58.3 \mathrm{FA}+8 \mathrm{CS}+7.7 \mathrm{CH}$ with $3.5 \%$ hydrogen peroxide foaming agent is still the most cost efficient.
\end{abstract}

Keywords: foam agents; alkali-activated cements; compressive strength; thermal conductivity; global warming potential; cost efficiency

\section{Introduction}

The increasing worldwide demand for energy, is a major cause of unsustainable development on our Planet. Between 2007 and 2030, energy demand will have risen around $40 \%$, reaching a total of 16.8 billion tonnes of equivalent petroleum-TEP (Pacheco-Torgal \& Jalali, 2011). The rise in energy consumption has two main causes, the increase in world population and the fact that there are an increasing number of people with access to electricity. In fact, currently, there are 1.5 billion people that still have no access to electricity (UN, 2010). Besides, since the urban human population will almost double, increasing from approximately 3.4 billion in 2009 to 6.4 billion in 2050 (WHO, 2014), this will dramatically increase electricity demand. Since buildings consume throughout their life cycle, more than $40 \%$ of all energy produced (OECD, 2003), this subsector has a high potential for reducing carbon dioxide emissions. The European Union has been producing legislation in the field of building's energy performance, which was materialised in the form of the European Energy Performance of Buildings Directive 2002/91/EC (EPBD), which in turn, has been recast in the form of the 2010/ 31/ EU by the European Parliament on 19 May 2010. One of the new aspects of the

\footnotetext{
*Corresponding author. Email: torgal@civil.uminho.pt
} 
EPBD that reflects an ambitious agenda on the reduction of the energy consumption is the introduction of the concept of nearly zero-energy building (Pacheco-Torgal, Cabeza, Mistretta, Kaklauskas, \& Granqvist, 2013). The use of thermal insulation materials constitutes the most effective way of mitigating heat loss in buildings, thus reducing heat energy needs, and therefore contributing to the nearly zero energy target. These materials are very important for the building material industry and represent a 21 billion $€$ market share (Pacheco-Torgal, 2014). However, most current insulation materials are associated with negative impacts in terms of toxicity. Polystyrene, for example contains anti-oxidant additives and ignition retardants, additionally, its production involves the generation of benzene and chlorofluorocarbons. On the other hand, polyurethane is obtained from isocyanates, which are widely known for their tragic association with the Bhopal disaster. Besides, they release toxic fumes when subjected to fire (PachecoTorgal, Jalali, \& Fucic, 2012). In terms of legislation, the European Union recently approved the Regulation (EU) 305/2011 (2011) related to the Construction Products Regulation that will replace the current Directive $89 / 106 /$ CEE, already amended by Directive 1993/68/EEC, known as the Construction Products Directive. Investigations in the field of geopolymers had an exponential increase after the research results of Davidovits (1979) who developed and patented binders obtained from the alkaliactivation of metakaolin, having named it after the term "geopolymer" in 1978. For the chemical designation of the geopolymer, Davidovits suggested the name "polysialates", in which Sialate is an abbreviation for aluminosilicate oxide. However, Provis and Van Deventer (2009) mentioned that the sialate nomenclature "implies certain aspects of the geopolymer gel structure which do not correspond to reality". Despite all the investigations published on these materials in the last decades, some aspects still needed to be further investigated especially concerning durability performance (Pacheco-Torgal, Abdollahnejad, Camões, Jamshidi, \& Ding, 2012; Pacheco-Torgal, Labrincha, Leonelli, Palomo, \& Chindaprasirt, 2014; Provis, 2013). In the last years, several papers were published on foam alkali-activated cements with enhanced thermal conductivity (Feng et al., 2015; Hlaváček, Šmilauer, Škvára, Kopecký, \& Šulc, 2015; Sanjayan, Nazari, Chen, \& Nguyen, 2015; Zhang, Provis, Reid, \& Wang, 2014). However, cost analysis was oddly avoided. Those authors strangely mentioned that low-cost alkali-activated cements materials could be produced. However, it is known that one of the shortcomings of alkali-activated cements is its non-cost efficiency. Also Abdollahnejad, PachecoTorgal, and Félix (2015) recently studied foam fly ash-based two-part $\left(\mathrm{NaOH}, \mathrm{NaSiO}_{3}\right)$ alkali-activated cements having report that the mixtures cost more than $300 \mathrm{euro} / \mathrm{m}^{3}$. This means that investigations concerning the development of low-cost foam alkali-activated cements are still needed. The discovery of one-part alkali-activated cements is considered a key event on the evolution of low-carbon alkali-activated cements technology in the "just add water" concept. Contrary to ordinary Portland cement (OPC)-based materials, alkali-activated cements use caustic activators that makes the handling and application of alkali-activated cements very difficult. That is why the alkali-activated cements based on the OPC concept of just add water to a powder are an important research line. However, investigations made so far on one-part alkali-activated cements show that these materials are associated with very low compressive strength (Koloušek et al., 2007; Peng, Wan, Shen, \& Xiao, 2014). Some authors even report a compressive strength decrease with time for one-part alkali-activated cements based on calcined red mud and sodium hydroxide blends (Ke, Bernal, Ye, Provis, \& Yang, 2015). Abdollahnejad, Hlavacek, Miraldo, Pacheco-Torgal, and Aguiar (2014) recently investigated onepart alkali-activated cements having obtained relevant compressive strength using fly 
ash and minor amounts of OPC. Since supply chain risks can limit the alkali-activated cements technology's wider adoption, (Van Deventer, Provis, \& Duxson, 2012) the use of minor volumes of OPC can help overcome this problem. Yang and Lee (2013) and Yang, Lee, Song, and Gong (2014) studied foam-ground granulated blast-furnace slag concrete produced with three alkali activators: $\mathrm{Ca}(\mathrm{OH})_{2}$ plus $\mathrm{Mg}\left(\mathrm{NO}_{3}\right)_{2}, \mathrm{Ca}(\mathrm{OH})_{2}$ plus $6.5 \% \mathrm{Na}_{2} \mathrm{SiO}_{3}$, and $2.5 \% \mathrm{Ca}(\mathrm{OH})_{2}$ plus $\mathrm{Na}_{2} \mathrm{SiO}_{3}$. These authors concluded that a unit binder content of approximately $400 \mathrm{~kg} / \mathrm{m}^{3}$ is required to achieve the minimum quality requirements specified by the Korean Industrial Standard for floor heating systems (Figure 1). This paper discloses results of a study on one-part foam alkali-activated cements based on fly ash and OPC blends floor heating system applications. It also includes global warming potential assessment and cost analysis.

\section{Experimental work}

\subsection{Materials and mix design}

The mixtures under investigation were based on the ones described in the international patent authored by Zheng, Van Deventer, and Duxson (2007) and whose mechanical properties and durability were already previously studied (Abdollahnejad, Pacheco-Torgal, Aguiar, \& Jesus, 2015; Abdollahnejad et al., 2014). The composition of the dry mix in this study was: kaolin, fly ash, OPC, sodium hydroxide $(\mathrm{NaOH})$, calcium hydroxide $\left(\mathrm{Ca}(\mathrm{OH})_{2}\right)$, water, and superplasticizer. Mortars were made with a sand having a maximum dimension of $4 \mathrm{~mm}$ and a density of $2660 \mathrm{~kg} / \mathrm{m}^{3}$. The OPC is of class I $42,5 \mathrm{R}$ type, containing between 95 and $100 \%$ of clinker content, a specific weight of $3.15 \mathrm{~g} / \mathrm{cm}^{3}$ and a Blaine fineness of $3842 \mathrm{~cm}^{2} / \mathrm{g}$ (Table 1). The superplasticizer (SP) used was SIKA $3002 \mathrm{HE}$. The referred SP was used to maintain a uniform consistency throughout the different mixes. The chemical composition of the fly ash complies with the minimum requirements indicated in EN-450-1 (2012) for use as a partial replacement of cement in concrete. Based on this standard, the fly ash was categorized as class $\mathrm{B}$ and group $\mathrm{N}$ for the loss of ignition and fineness, respectively. Also, the material in question has a specific weight of $2.42 \mathrm{~g} / \mathrm{cm}^{3}$ and a chemical composition as shown in Table 1. The kaolin has a BET surface area of $210.000 \mathrm{~cm}^{2} / \mathrm{g}$ and its particle size is shown in Figure 1. This is crucial information as this parameter influences the dehydroxylation temperature of kaolin. The DTA/TGA curves for kaolin are presented in Figure 2. A well-defined endothermic DTA peak and sharp weight loss in the TGA

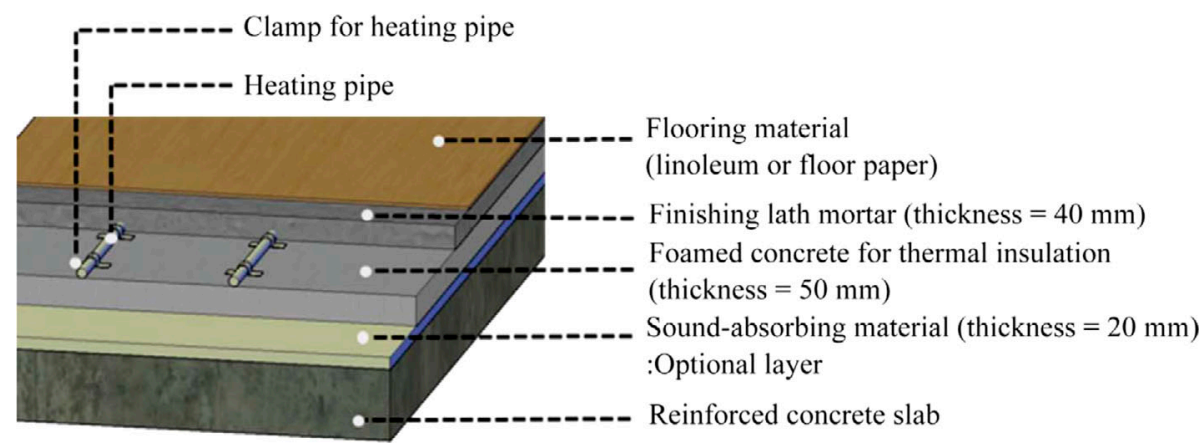

Figure 1. Details of sections of typical floor heating system (Peng et al., 2014). 
Table 1. Chemical composition of OPC, kaolin and fly ash.

\begin{tabular}{lccc}
\hline Constituents (\%) & OPC & Kaolin & Fly ash \\
\hline $\mathrm{SiO} 2$ & 20.17 & 61.26 & 49.12 \\
$\mathrm{Al}_{2} \mathrm{O}_{3}$ & 4.41 & 27.0 & 27.3 \\
$\mathrm{Fe}_{2} \mathrm{O}_{3}$ & 3.40 & 3.08 & 8.19 \\
$\mathrm{CaO}$ & 62.97 & .159 & 2.36 \\
$\mathrm{MgO}$ & 1.80 & .161 & 1.42 \\
$\mathrm{Na}$ & .20 & .096 & .99 \\
$\mathrm{~K}_{2} \mathrm{O}$ & .79 & 6.622 & 3.34 \\
$\mathrm{SO}_{3}$ & 3.20 & .048 & - \\
$\mathrm{TiO}_{2}$ & - & .994 & 2.32 \\
$\mathrm{P}_{2} \mathrm{O}_{5}$ & - & .325 & - \\
$\mathrm{Zn}^{\mathrm{ZrO}}$ & - & .005 & - \\
$\mathrm{Oter}_{2}$ oxides & - & .056 & - \\
\hline
\end{tabular}

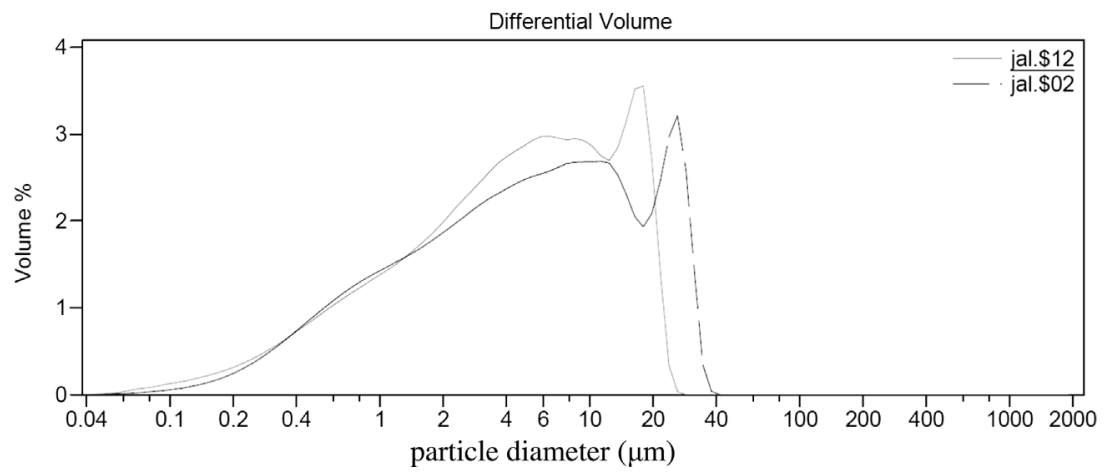

Figure 2. Kaolin particle diameter obtained with and without a deflocculating agent.

curve appears between 550 and $600{ }^{\circ} \mathrm{C}$ (Figure 3). This loss results from the transition to the amorphous and more reactive metakaolin phase. A mixture of kaolin and sodium hydroxide calcined in a furnace at $650{ }^{\circ} \mathrm{C}$ during $140 \mathrm{~min}$ is referred as calcined stuff (CS). A mixture of kaolin and sodium hydroxide was calcined in a furnace at $650{ }^{\circ} \mathrm{C}$ during $140 \mathrm{~min}$. The cooled mixture was then ground into powder. Three foaming agents were used, namely aluminium powder (.5-1.5\%), $\mathrm{NaBO}_{3}(3-5 \%)$ and $\mathrm{H}_{2} \mathrm{O}_{2}$ (3-5\%). Table 2 shows the mix composition of one-part alkali-activated cements mortars.

\section{Experimental procedures}

Compressive strength was performed on $50 \times 50 \times 50 \mathrm{~mm}^{3}$ mortar specimens and was obtained for each mixture from an average of 3 cubic specimens. The specimens were tested after 28 days of curing. The specimens were immersed in water at room temperature for $24 \mathrm{~h}$. First, the weight of the specimens was recorded while suspended by a thin wire and completely submerged in water is recorded as Wim (immersed weight). After that, the specimens were removed from water, and placed for $1 \mathrm{~min}$ on a wire mesh 
Table 2. Composition of one-part alkali-activated mixtures.

\begin{tabular}{|c|c|c|c|c|c|c|c|}
\hline Mix & $\begin{array}{l}\text { OPC } \\
(\%)\end{array}$ & $\begin{array}{l}\text { Fly ash } \\
(\%)\end{array}$ & $\begin{array}{c}\text { Calcined } \\
\text { kaolin and sodium } \\
\text { hydroxide }(\%)\end{array}$ & $\begin{array}{l}\mathrm{Ca}(\mathrm{OH})_{2} \\
(\%)\end{array}$ & $\begin{array}{l}\text { Sand } \\
(\%)\end{array}$ & $\begin{array}{l}\text { SP } \\
(\%)\end{array}$ & $\begin{array}{l}\mathrm{w} / \\
\mathrm{b}\end{array}$ \\
\hline $100 \mathrm{OPC}$ & 100 & - & - & - & 80 & .8 & .35 \\
\hline 30 OPC_70 FA & 30 & 70 & - & - & & & \\
\hline $\begin{array}{c}30 \mathrm{OPC}-58.3 \mathrm{FA} 44 \\
\mathrm{CS} 7.7 \mathrm{CH}\end{array}$ & 30 & 58.3 & 4 & 7.7 & & & \\
\hline $\begin{array}{l}26 \text { OPC_ } 58.3 \text { FA_8 } \\
\text { CS } 7.7 \mathrm{CH}\end{array}$ & 26 & 58.3 & 8 & 7.7 & & & \\
\hline $\begin{array}{l}18 \text { OP̄C558.3 FA_16 } \\
\text { CS_7.7 } \mathrm{CH}\end{array}$ & 18 & 58.3 & 16 & 7.7 & & & \\
\hline
\end{tabular}

allowing water to drain, then visible surface water was removed with a damp cloth and weight is recorded as Wsat (saturated weight). All specimens were then placed in a ventilated oven at $105{ }^{\circ} \mathrm{C}$ for not less than $24 \mathrm{~h}$ while allowing for two successive weightings at intervals of $2 \mathrm{~h}$ to show an increment of loss not greater than $0.1 \%$ of last previously determined weight of the specimen. The weight of the dried specimens was recorded as Wdry (oven-dry weight). The bulk desnity was assessed using the water saturation method. Thermal conductivity was assessed using an Alambeta instrument developed at the Technical University of Liberec, Czech Republic. During the measurements, the initial temperature of the samples and the base of the Alambeta were kept at $22-24{ }^{\circ} \mathrm{C}$, and the relative humidity was recoreded as being in the range of $55-65 \%$. To investigate the effect of the temperature drop on the thermal properties of the samples, the temperature of the measuring head, at first, was $10{ }^{\circ} \mathrm{C}$ higher than the environmental temperature. During the second set of measurements, the measuring head temperature was $40{ }^{\circ} \mathrm{C}$ higher than the base plate.To assess the crystalline structure of these mixtures, X-ray diffraction (XRD) analysis was employed. Powder XRD was implemented on a Bruker D8 Discover with $\mathrm{Cu}-\mathrm{K} \alpha$ radiation $(\lambda=1,54060 \AA)$ at $40 \mathrm{kV}$ and $40 \mathrm{~mA}$. Each sample was scanned from $5^{\circ}$ to $70^{\circ}$ at a speed of $.04^{\circ} \mathrm{s}-1$. The analysis for phase identification was performed using analytical software EVA. For examination through scanning electron microscopy (SEM), the samples were covered with 40-nm film of AuPd (80-20 weight \%); in a high-resolution sputter coater, 208HR Cressington Company, coupled to a MTM-20 Cressington High Resolution Thickness Controller. Ultrahigh resolution field emission gun SEM, NOVA 200 Nano SEM and FEI Company were also used. Backscattering Electron images were achieved through an acceleration voltage of $15 \mathrm{kV}$. Chemical analyses of samples were performed with the Energy Dispersive Spectroscopy (EDS) technique, using an EDAX $\mathrm{Si}(\mathrm{Li})$ detector with an acceleration voltage of $20 \mathrm{kV}$.

\section{Results and discussion}

\subsection{XRD, SEM and EDS}

The results of XRD are presented in Figure 4. A small mullite crystalline phase is detected in all the calcined kaolin-based mixtures. A clear calcite peak is common to the calcined kaolin mixtures. The clear crystalline structure in these mixtures contrasts with the amorphous structures of traditional two-part alkali-activated cements. The different foaming agents (aluminum powder and hydrogen peroxide) seem not to have altered the crystalline phases of the hardened material, the exception being the clear 


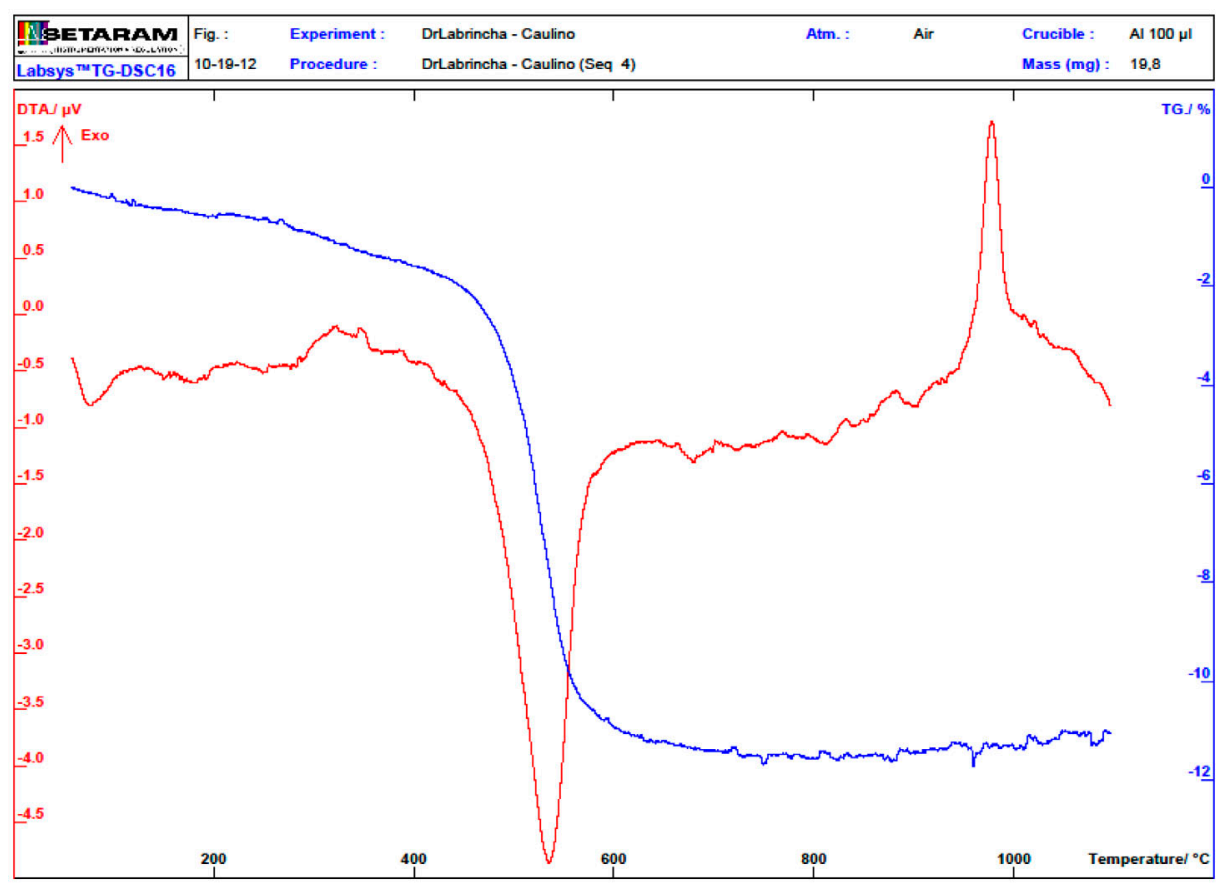

Figure 3. DTA/TGA curves for kaolin.

Table 3. EDS atomic ratios.

\begin{tabular}{|c|c|c|c|c|c|c|c|c|}
\hline & \multirow{2}{*}{\multicolumn{2}{|c|}{$\begin{array}{l}100 \mathrm{OPC} \\
1.5 \% \mathrm{AL}\end{array}$}} & \multicolumn{6}{|c|}{30 OPC_58.3 FA_4 CS_7.7 CH } \\
\hline & & & \multicolumn{3}{|c|}{$3.5 \% \mathrm{H}_{2} \mathrm{O}_{2}$} & \multirow{2}{*}{$\begin{array}{c}5 \% \mathrm{H}_{2} \mathrm{O}_{2} \\
\mathrm{Z}_{1}\end{array}$} & \multicolumn{2}{|c|}{$.5 \% \mathrm{AL}$} \\
\hline & $\mathrm{Z}_{1}$ & $\mathrm{Z}_{2}$ & $\mathrm{Z}_{1}$ & $Z_{2}$ & $\mathrm{Z}_{3}$ & & $\mathrm{Z}_{1}$ & $Z_{2}$ \\
\hline $\mathrm{SiO}_{2} / \mathrm{Al}_{2} \mathrm{O}_{3}$ & 1.41 & 3.96 & 8.81 & 6.08 & 4.41 & 5.86 & 2.08 & 5.84 \\
\hline $\mathrm{Al}_{2} \mathrm{O}_{3} / \mathrm{Na}_{2} \mathrm{O}$ & - & - & .47 & 2.73 & 4.53 & - & 6.20 & 6.66 \\
\hline $\mathrm{CaO} / \mathrm{SiO}_{2}$ & 6.57 & 3.32 & 5.08 & .46 & .08 & 6.55 & 2.40 & .42 \\
\hline $\mathrm{Na}_{2} \mathrm{O} / \mathrm{CaO}$ & - & - & .04 & .13 & .61 & - & .03 & .06 \\
\hline $\mathrm{MgO} / \mathrm{Al}_{2} \mathrm{O}_{3}$ & .57 & 3.84 & 2.32 & .54 & - & - & - & - \\
\hline
\end{tabular}

calcite silicate oxide in the mixture containing 5\% oxygen peroxide. Results of SEM are presented in Figure 5. Also the mixtures have the following compressive strength after 28 days of curing $(2.3,2.2,7$ and $8.7 \mathrm{MPa})$. The mixtures associated to lower compressive strength show less dense microstructure. This is clearer in the mixture 30 OPC_58.3 FA_4 CS_7.7 $\mathrm{CH}\left(5 \% \mathrm{H}_{2} \mathrm{O}_{2}\right)$ with $5 \%$ hydrogen peroxide foaming agent. Concerning the EDS molar ratios (Table 3) several areas $\left(Z_{2}\right.$ e $Z_{3}$ in mixture with $3.5 \%$ $\mathrm{H}_{2} \mathrm{O}_{2}$ and $\mathrm{Z}_{2}$ in mixture with $0.5 \%$ aluminum powder) in the one-part geopolymer mixtures show lower $\mathrm{C} / \mathrm{S}$ ratio typical of sodium incorporation in the $\mathrm{CSH}$ phase into Na-C-S-H gel (Macphee, 1989), this phase usually evolves into compositions with higher calcium and lower aluminum content (with the $\mathrm{C}-\mathrm{A}-\mathrm{S}-\mathrm{H}$ gel proposed to be more stable than $\mathrm{N}-\mathrm{A}-\mathrm{S}-\mathrm{H}$, at high $\mathrm{pH}$ ) (Garcia-Lodeiro, Fernández-Jiménez, \& Palomo, 2013). 
d)

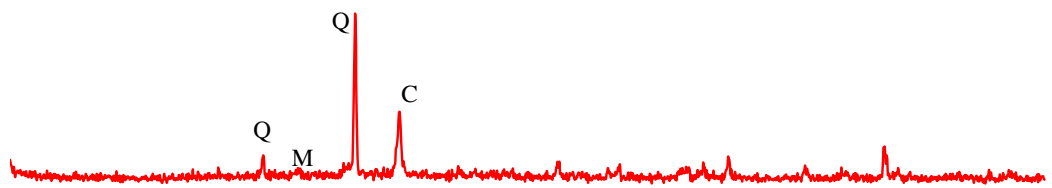

c)

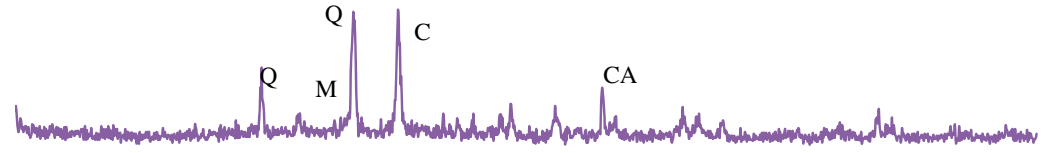

b)

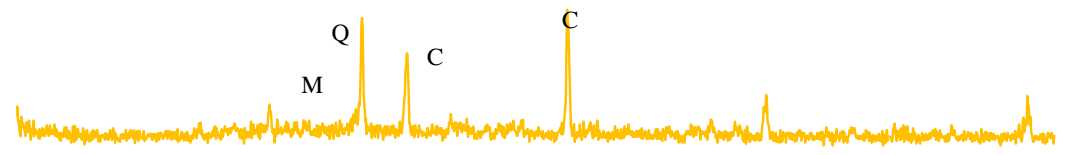

a)

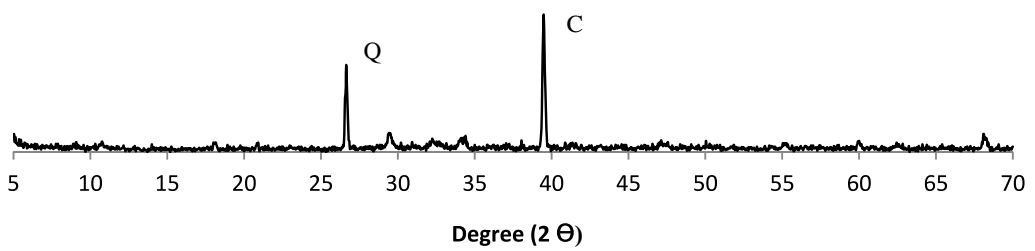

Figure 4. XRD patterns of: (a) $100 \mathrm{OPC}(1.5 \% \mathrm{AL})$; (b) 30 OPC_58.3 FA_4 CS_7.7 CH (.5\% $\mathrm{AL})$; (c) $30 \mathrm{OPC} 58.3 \mathrm{FA} \_4 \mathrm{CS} 77.7 \mathrm{CH}\left(5 \% \mathrm{H}_{2} \mathrm{O}_{2}\right)$; (d) $30 \mathrm{OPC} \overline{5} 8.3 \mathrm{FA} \overline{4} \mathrm{CS} \overline{7} .7 \mathrm{CH}(3.5 \%$ $\left.\mathrm{H}_{2} \mathrm{O}_{2}\right) ; \mathrm{M}$ - Mullite; Q - Quartz; $\mathrm{C}$ - Calcite; CA - Calcite silicate oxide.

\subsection{Compressive strength}

Compressive strength results for one-part alkali-activated mortars are shown in Figure 6. For mortars based only in Portland cement, the increase of the aluminium content leads to a decrease in compressive strength except when the aluminium content increases from 1.2 to $1.5 \%$, which leads to the increase of compressive strength. The reaction of aluminium powder in the alkaline environment liberates $\mathrm{Al}_{2} \mathrm{O}^{-}$and hydrogen gas $\left(\mathrm{H}_{2}\right)$ according to Equation (1) (Arellano Aguilar, Burciaga Díaz, \& Escalante García, 2010):

$$
8 \mathrm{Al}+2 \mathrm{OH}^{-}+2 \mathrm{H}_{2} \mathrm{O} \rightarrow 4 \mathrm{Al}_{2} \mathrm{O}^{-}+3 \mathrm{H}_{2}
$$

When the $\mathrm{NaBO}_{3}$ is used as foaming agent in Portland cement mortars, the compressive strength decreases with the increase in the foaming agent content. Although one exception is detected, when $\mathrm{NaBO}_{3}$ increased from 3 to $3.5 \%$ the compressive strength increases. Concerning the use of $\mathrm{H}_{2} \mathrm{O}_{2}$, the increase of foaming agent shows a minor increase in the compressive strength but when the foaming agent is increased from $4 \%$ to $4.5 \%$, the compressive strength decreased. Comparing the performance of the different foaming agents on Portland cement mortars it is observed that the higher compressive strength $(20.24 \mathrm{MPa})$ was recorded for a $.5 \%$ AL content. Concerning the mixture 30 OPC_70 FA, the increase of the aluminium content results in a decrease in compressive strength except when its increase from 1 to $1.2 \%$ led to slight compressive strength increase. When the $\mathrm{NaBO}_{3}$ is used, a trend on compressive strength decrease with foaming agent increase can be found. With respect to the use of $\mathrm{H}_{2} \mathrm{O}_{2}$, the increase in 
(a)
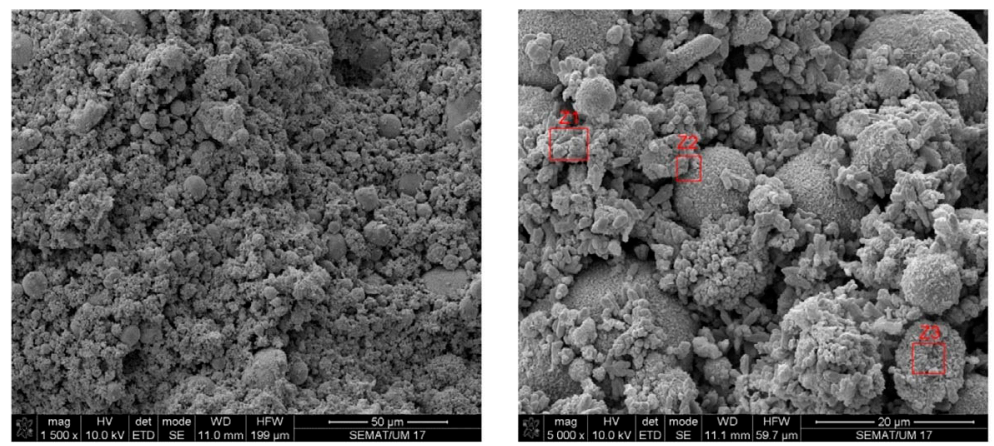

(b)
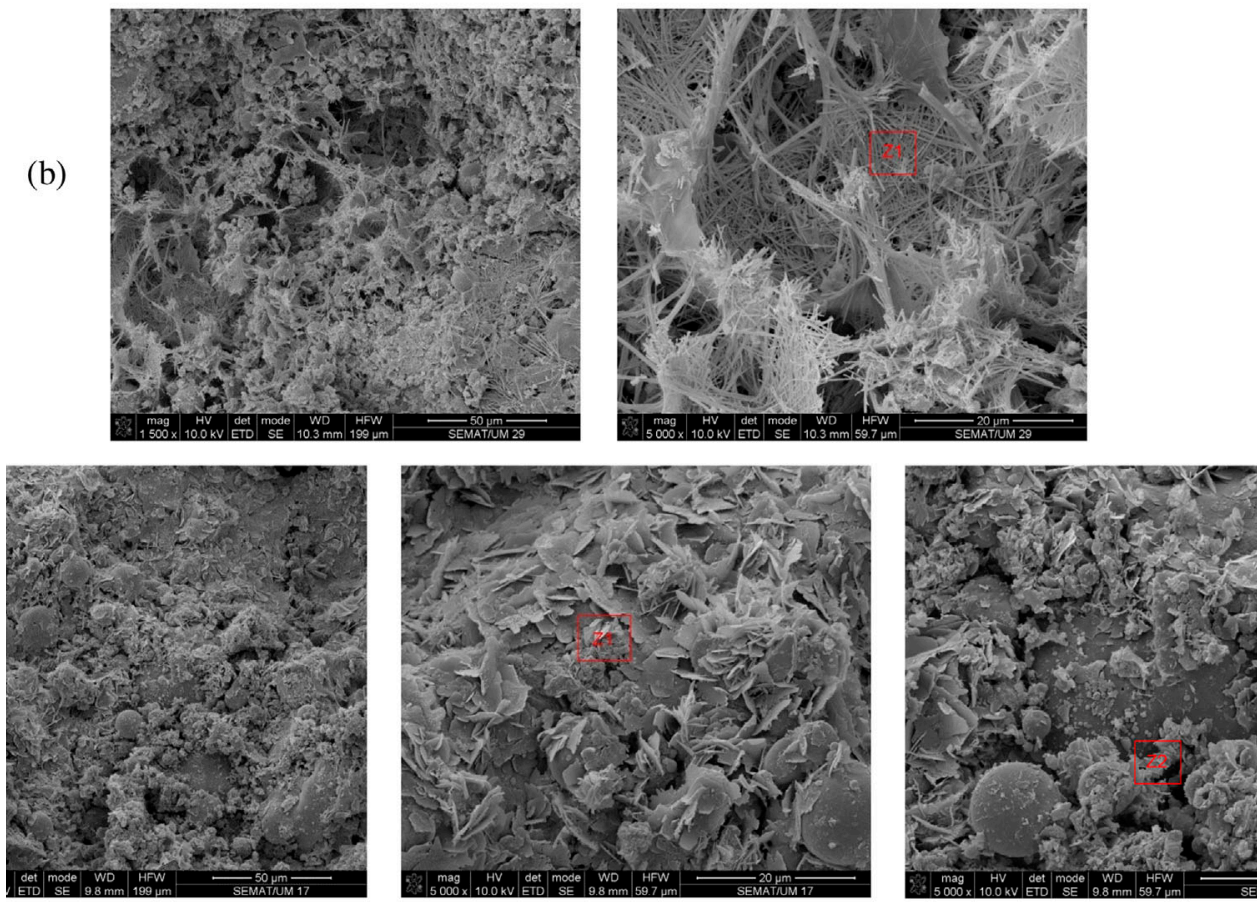

(d)
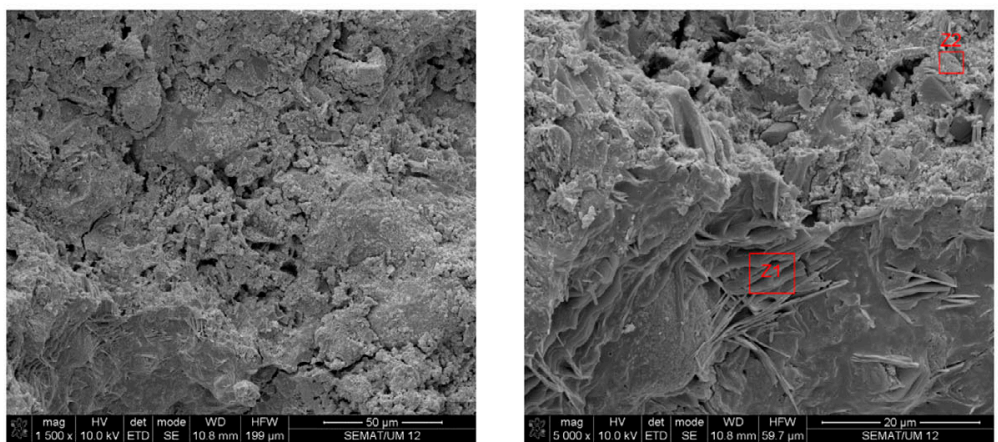

Figure 5. SEM images of: (a) $30 \mathrm{OPC} 58.3 \mathrm{FA} 4 \mathrm{CS} 7.7 \mathrm{CH}\left(3.5 \% \mathrm{H}_{2} \mathrm{O}_{2}\right)$; (b) $30 \mathrm{OPC} 58.3$ FA_4 CS_7.7 $\mathrm{CH}\left(5 \% \mathrm{H}_{2} \mathrm{O}_{2}\right)$; (c) 30 OPC_58.3 FA_ 4 CS_7.7 $\mathrm{CH}(.5 \% \mathrm{AL})$; (d) 100 OPC $(1 . \overline{5 \%} \mathrm{AL})$. 
Table 4. Global warming potential of the constituents of the mortars (taken from the Ecoinvent database).

\begin{tabular}{lc}
\hline Constituents of mortars & $\mathrm{GWP}\left(\mathrm{kg} \mathrm{CO}_{2} \mathrm{eq}\right)$ \\
\hline Ordinary Portland cement (OPC) & $8.44 \times 10^{-1}$ \\
Superplasticizer & $7.49 \times 10^{-1}$ \\
Fine sand, aggregates & $2.40 \times 10^{-3}$ \\
Free water & $1.55 \times 10^{-4}$ \\
Metakaolin & $9.24 \times 10^{-2}$ \\
Fly ash & $5.26 \times 10^{-3}$ \\
Soda powder & $2.24 \times 10^{0}$ \\
Sodium silicate & $1.76 \times 10^{0}$ \\
Ca(OH) $)_{2}$ - hydraulic lime & $4.16 \times 10^{-1}$ \\
Oxygen peroxide $_{\text {Sodium perborate }}$ & $8.01 \times 10^{0}$ \\
Aluminum powder & $3.77 \times 10^{0}$ \\
\hline
\end{tabular}

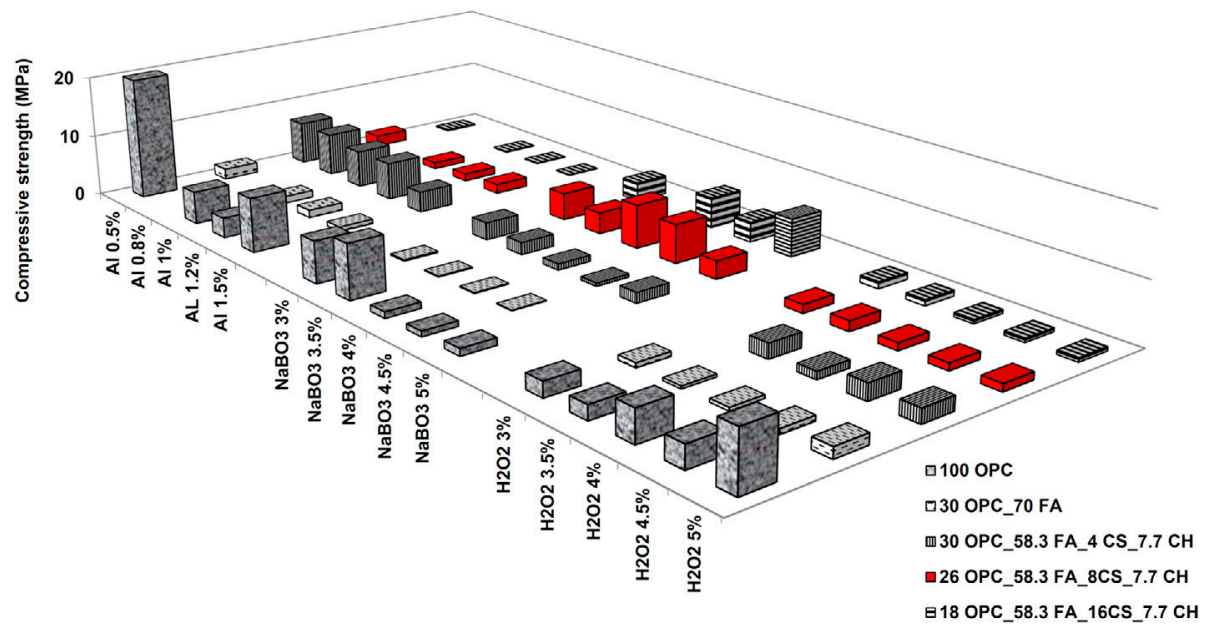

Figure 6. Compressive strength.

foaming agent from 3 to $3.5 \%$ leads to a decrease of the compressive strength. In an alkaline environment, oxygen peroxide decomposes into water and oxygen according to Equations (2) and (3) (Damjanovic, Genshaw, \& Bockris, 1967):

$$
\begin{gathered}
\mathrm{H}_{2} \mathrm{O}_{2}+\mathrm{OH}^{-} \rightarrow 4 \mathrm{Al}_{2} \mathrm{O}^{-}+\mathrm{H}_{2} \mathrm{O} \\
\mathrm{HO}_{2}^{-}+\mathrm{H}_{2} \mathrm{O}_{2} \rightarrow \mathrm{H}_{2} \mathrm{O}+\mathrm{O}_{2}+\mathrm{OH}^{-}
\end{gathered}
$$

In general, it can be stated that, the results gathered for the compressive strength of the mixture 30 OPC_70 FA with different foaming agents are taking place in a lower range (in comparison to other compressive strengths of one-part alkali-activated mortars). Regarding the mixture 30 OPC_58.3 FA_4 CS_7.7 $\mathrm{CH}$ an increase of the aluminium content results in a reduction in compressive strength. Increasing $\mathrm{NaBO}_{3}$ from 1 to $5 \%$ 
reduced the compressive strength with some exceptions. The exceptions were found when the $\mathrm{NaBO}_{3}$ content increased from 1 to $2 \%$ and 4.5 to $5 \%$. No specific trend was observed in the compressive strength of the mixture 30 OPC_58.3 FA_4 CS_7.7 CH that used $\mathrm{H}_{2} \mathrm{O}_{2}$. Comparing the performance of the different foaming agents the higher compressive strength $(7 \mathrm{MPa})$ took place for a $.5 \%$ AL content. Additionally, two similar compressive strengths recorded for this mixture: one with $1 \% \mathrm{AL}(6 \mathrm{MPa})$ and other with $1.2 \% \mathrm{AL}(6.04 \mathrm{MPa})$. Results of the compressive strength in mixture 26 OPC_58.3 FA_8 CS_7.7 CH show that there is an increase in compressive strength when the Al content increased. The increase in compressive strength can be due to an increase in density related to pore collapses, as suggested by authors (Masi, Rickard, Vickers, Bignozzi, \& van Riessen, 2014). Those authors also confirm that aluminium powder is very reactive, thus requiring a much smaller amount (than hydrogen peroxide) for obtaining similar densities. However, since the former costs 33 times more than the latter (Table 4), it is important to compare the economic performance of the different mixtures (Section 6). Nevertheless, an exception was observed when the aluminium content increased from .5 to $1 \%$, since, no specific trend was observed in compressive strength of the mixture 30 OPC_58.3 FA_4 CS_7.7 $\mathrm{CH}$ that used $\mathrm{NaBO}_{3}$. The higher compressive strength $(6.99 \mathrm{MPa})$ was registered for a $4 \% \mathrm{NaBO}_{3}$ content. Additionally, concerning the mixture 18 OPC_58.3 FA_16 CS_7.7 CH, an increase in the aluminium content leads to a decrease in compressive strength. When the $\mathrm{NaBO}_{3}$ is used as a foaming agent, a trend on compressive strength increase with foaming agent increase can be noticed, except when the $\mathrm{NaBO}_{3}$ increase from 4 to $4.5 \%$ leading to a reduction in compressive strength. With respect to the use of $\mathrm{H}_{2} \mathrm{O}_{2}$, the increase of the foaming agent results in a reduction of the compressive strength. By comparing the performance of the different foaming agents, it can be concluded that the highest compressive strength $(6.11 \mathrm{MPa})$ was measured for a $5 \% \mathrm{NaBO}_{3}$ content. The overall results show that several mixtures show a compressive strength similar to the one presented by commercial cellular concrete blocks (6.5 MPa). However, most mixtures comply with the compressive strength requirement $(\geq 1.4 \mathrm{MPa})$ of the grades 4 and 5 of the Korean Industrial Standard code for foam concrete for floor heating systems (Yang et al., 2014).

\subsection{Water absorption by immersion}

The results of water absorption of one-part alkali-activated mortars are shown in Figure 7. For mortars based only in Portland cement, the increase of the aluminium content does not lead to a relevant change in water absorption. In fact, when it increases from 1.2 to $1.5 \%$, the water absorption decreases slightly. When $\mathrm{NaBO}_{3}$ is used as a foaming agent in Portland cement mortars, a trend on water absorption increase with foaming agent content increase can be noticed. However, some exceptions are detected such as the rise from $3 \%$ to $3.5 \%$ and the increase from 4 to $4.5 \%$ that lead to a reduction in water absorption. Concerning the use of $\mathrm{H}_{2} \mathrm{O}_{2}$, the increase of foaming agent from 3 to $3.5 \%$ shows a minor growth in the water absorption, but when the foaming agent is increased above $3.5 \%$ no water absorption increase is detected. Comparing the performance of the different foaming agents on Portland cement mortars, it can be seen that the higher water absorption $(62 \%)$ took place for a $5 \% \mathrm{NaBO}_{3}$ content. However, this mixture shows a foaming efficiency (water absorption/foaming agent content $=12$ ) that is lower than that of other mixtures based on an aluminium foaming agent. These mixtures show higher water absorption levels with just $.5 \%$ content $($ efficiency $=90$ ). Concerning the mixtures 30 OPC_70 FA, the increase of the aluminium content leads to 


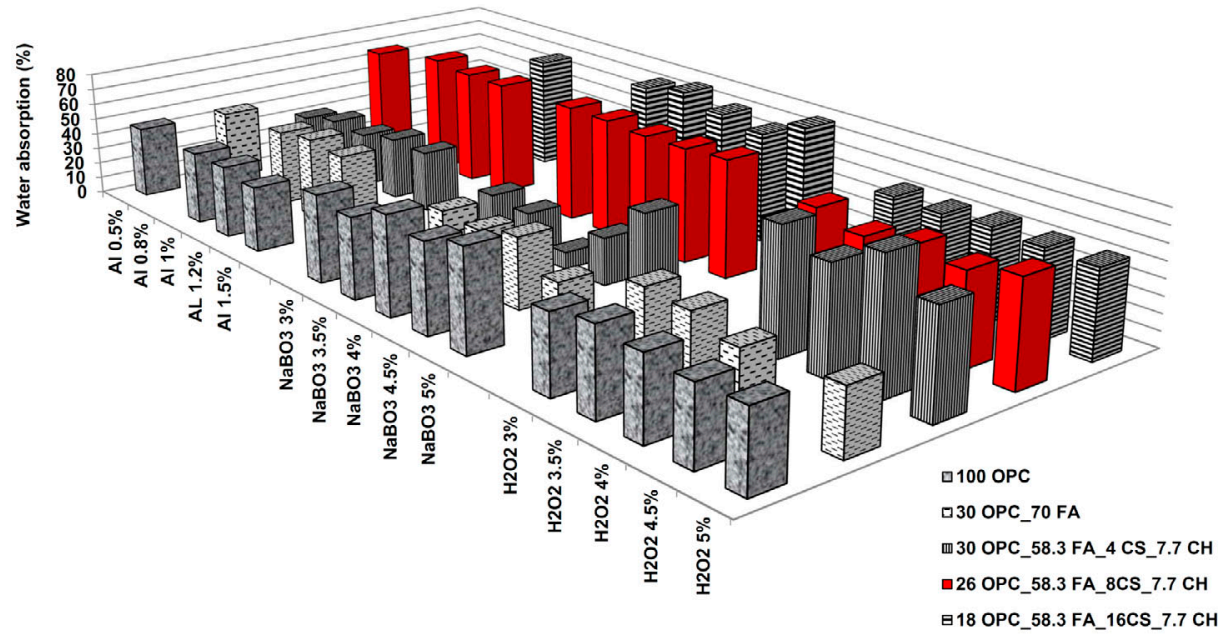

Figure 7. Water absorption.

a slight increase in water absorption. When the aluminium increases from $1.2 \%$ to $1.5 \%$ a slight water absorption decrease was detected. When the $\mathrm{NaBO}_{3}$ is used as foaming agent in this mixture, a trend on water absorption decrease with foaming agent increase was registered. However, there was an exception. When the $\mathrm{NaBO}_{3}$ increased from 4 to $4.5 \%$, this led to a water absorption reduction. Regarding the use of $\mathrm{H}_{2} \mathrm{O}_{2}$, the increase of foaming agent depicts a minor decrease in the water absorption. Yet, when the foaming agent is increased above $4 \%$, a slight increase in water absorption is detected. When comparing the performance of the different foaming agents on the mixture 30 OPC 70 $\mathrm{FA}$, it is revealed that the higher water absorption (50.53\%) was recorded for $1.5 \%$ AL content. With respect to the mixtures 30 OPC_58.3 FA_4 CS_7.7 $\mathrm{CH}$, an increase of the aluminium content leads to an increase of water absorption. On the other hand, the increase from .8 to $1 \%$ and 1.2 to $1.5 \%$ decreases the water absorption. When the $\mathrm{NaBO}_{3}$ is used as foaming agent, a decrease was detected by increasing the foaming agent content, although some exceptions were detected from 1 to $2 \%$ and 4 to $5 \%$ (which led to water absorption increase). Concerning the use of $\mathrm{H}_{2} \mathrm{O}_{2}$, the increase of the foaming agent leads to a reduction in the water absorption. One exception was observed concerning the increase of the foaming agent from 4 to $4.5 \%$ which lead to an increase in water absorption. Comparing the performance of the different foaming agents it is found that the higher water absorption (81.07\%) took place for a $4.5 \%$ $\mathrm{H}_{2} \mathrm{O}_{2}$ content. This corresponds to an efficiency of $(81.07 / 4.5=18)$ while Al mixtures show high efficiencies $(40 / 1.2=33.3)$. Concerning the mixtures 26 OPC_58.3 FA_8 CS_7.7 CH, an increase of the aluminium content leads to a slight decrease in water absorption. An exception was noticed when the use of AL increased from .5 to $1 \%$ and a minor increase in the water absorption was also detected. When the $\mathrm{NaBO}_{3}$ is used as the foaming agent the water absorption is almost constant, regardless of the increase on the foaming agent content. With respect to the use of $\mathrm{H}_{2} \mathrm{O}_{2}$, the increase of the foaming agent shows no change in the water absorption. The performance of different foaming agents on this mixture showed that the higher water absorption $(72.72 \%)$ was registered for a $3 \% \mathrm{NaBO}_{3}$ content. Additionally, some similarly high water absorptions were observed for this mixture with $1.2 \% \mathrm{AL}$ (72.31\%), 1.5\% $\mathrm{AL}(72.22 \%), 3.5 \% \mathrm{NaBO}_{3}$ 
(72.27\%), and $5 \% \mathrm{NaBO}_{3}(72.70 \%)$. Concerning the mixture 30 OPC_58.3 FA_16 CS_7.7 CH, an increase of the aluminium content leads to an increase in water absorption. When the $\mathrm{NaBO}_{3}$ is used, a trend on water absorption reduction with foaming agent content increase was noticed. However, the increase of $\mathrm{NaBO}_{3}$ from 3 to $3.5 \%$ and the increase of $\mathrm{NaBO}_{3}$ from 4.5 to $5 \%$ lead to a water absorption increase. Regarding the use of $\mathrm{H}_{2} \mathrm{O}_{2}$, by increasing foam agent content no increase in water absorption was discovered. Comparing the performance of the different foaming agents on the mixture 30 OPC 58.3 FA_16 CS_7.7 CA it can be seen that the higher water absorption $(81.48 \%)$ took place for a $5 \% \mathrm{NaBO}_{3}$ content.

\subsection{Bulk density}

The results of the bulk density of one-part alkali-activated mortars are shown in Figure 8. For mortars based only in Portland cement, an increment in the aluminium content leads to a decrease in bulk density. When the $\mathrm{NaBO}_{3}$ is employed in Portland cement mortars, a trend on bulk density decrease with foaming agent content increase can be noticed. Concerning the use of $\mathrm{H}_{2} \mathrm{O}_{2}$, the increase of the foaming agent shows a minor increase in the bulk density, but when the foaming agent is increased from 4 to $4.5 \%$ slight reduction in bulk density was detected. Regarding the performance of the different foaming agents on Portland cement mortars, it is revealed that the lowest bulk density $\left(1067 \mathrm{~kg} / \mathrm{m}^{3}\right)$ was recorded for a $3 \% \mathrm{H}_{2} \mathrm{O}_{2}$ content. Concerning the mixture 30 OPC 70 FA the increase of the aluminium content leads to decrease in bulk density except when it increases from 1 to $1.2 \%$ leading to a slight bulk density increase. When the $\mathrm{NaBO}_{3}$ is used, a trend can be noticed on bulk density increase. Regarding the use of $\mathrm{H}_{2} \mathrm{O}_{2}$, the increase of the foaming agent from 3 to $4 \%$ shows a decrease in the bulk density. Yet, when the foaming agent is increased above $4 \%$ an increase in the bulk density is registered. The lowest bulk density $\left(785 \mathrm{~kg} / \mathrm{m}^{3}\right)$ took place for a $4.5 \% \mathrm{H}_{2} \mathrm{O}_{2}$ content. In respect to the results of bulk density for mixture 30 OPC_58.3 FA_4 CS_7.7 $\mathrm{CH}$, increasing the aluminium content leads to a reduction on bulk density, except when

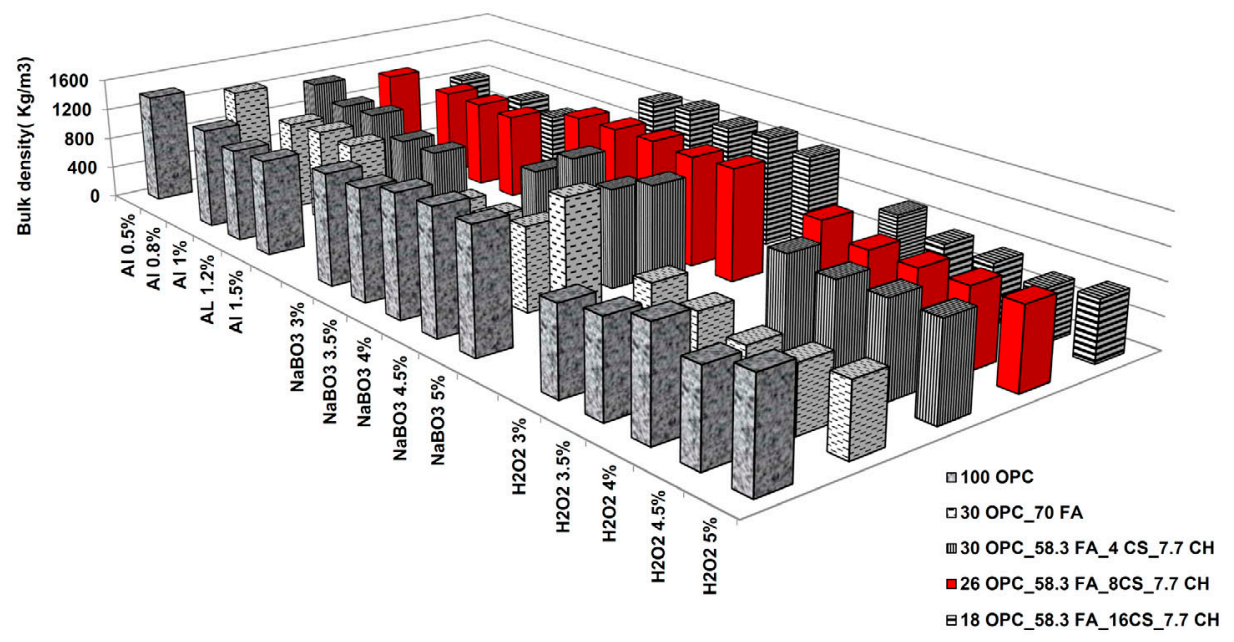

Figure 8. Bulk density. 
it increases from $.8 \%$ to $1 \%$ which lead to a slight bulk density increase. Increasing the $\mathrm{NaBO}_{3}$ content results in increasing the bulk density, except when the former increases from 4 to $4.5 \%$, situation that leads to a slight bulk density decrease. Concerning the use of $\mathrm{H}_{2} \mathrm{O}_{2}$, the increase of foaming agent content shows a constant trend in bulk density results. Comparing the obtained results by using different foaming agents it is observed that the lowest bulk density $\left(821 \mathrm{~kg} / \mathrm{m}^{3}\right)$ took place for a $1.2 \%$ AL content. Concerning the mixture 26 OPC_58.3 FA_8 CS_7.7 CH, an increase in the aluminium content from .5 to $1 \%$ leads to slight increase in bulk density. On increasing Al content by more than $.8 \%$, a constant trend in bulk density (with no increase) was detected. With respect to the increase in $\mathrm{NaBO}_{3}$ content as foaming agent, no change was observed. When $\mathrm{NaBO}_{3}$ content increased from 4 to $4.5 \%$ a slight increase in bulk density was noticed. The use of $\mathrm{H}_{2} \mathrm{O}_{2}$ showed a slight decrease from 3 to $3.5 \%$, while increasing $\mathrm{H}_{2} \mathrm{O}_{2}$ content by more than $3.5 \%$ did not show any change in bulk density. Comparing the results obtained from using different foaming agents, it is revealed that the lowest bulk density $\left(980 \mathrm{~kg} / \mathrm{m}^{3}\right)$ was measured for a $4 \% \mathrm{H}_{2} \mathrm{O}_{2}$ content. Concerning the mixture 18 OPC 58.3 FA_16 CS_7.7 CH. the increase of the aluminium content leads to reduction of bulk density. On the other hand, increasing the $\mathrm{NaBO}_{3}$ content, results in a reduction of bulk density. However some exceptions were noticed. Increasing the $\mathrm{NaBO}_{3}$ from 3 to $3.5 \%$ and from 4 to $4.5 \%$ leads to slight increase in bulk density. The increase in use of $\mathrm{H}_{2} \mathrm{O}_{2}$ leads to decrease of bulk density. The lowest bulk density $\left(654 \mathrm{~kg} / \mathrm{m}^{3}\right)$ was recorded for a $4.5 \% \mathrm{H}_{2} \mathrm{O}_{2}$ content.

\subsection{Thermal conductivity}

Figure 9 presents the results of the thermal conductivity performance of some one-part foam alkali-activated mixtures. Thermal conductivity test were not carried out on all one-part alkali-activated mixtures. Instead, two criteria were considered to select the mixtures for thermal conductivity testing, (a) Mixtures with compressive strength greater than $2 \mathrm{MPa}$; (b) Mixtures with bulk density lower than $1100 \mathrm{~kg} / \mathrm{m}^{3}$. The lowest thermal conductivity performance $(.132 \mathrm{~W} / \mathrm{m} \mathrm{K})$ was recorded for one-part alkali-activated mortars, in mix $30 \mathrm{OPC}+58.3 \mathrm{FA}+4 \mathrm{CS}$-7.7 $\mathrm{CH}$ _and $1.2 \% \mathrm{Al}$. Furthermore, a close value of thermal conductivity was measured for the same mixture with $1.5 \%$ aluminum powder. As the thermal conductivity of commercial autoclaved aerated concrete masonry blocks (Ytong) is around $(.17 \mathrm{~W} / \mathrm{m} \mathrm{K})$, similar thermal conductivity performances can be considered acceptable for thermal insulators like cementitious materials. The mixture 26 OPC +58.3 FA +8 CS_7.7 CH with $3.5 \%$ hydrogen peroxide shows an acceptable thermal conductivity of $.16 \mathrm{~W} / \mathrm{m} . \mathrm{K}$ because it fits the threshold of the grades 4 and 5 of the Korean Industrial Standard code for foam concrete for floor heating systems (Yang et al., 2014).

\section{Global warming potential}

The global warming potential GWP $\left(\mathrm{KgCO}_{2} \mathrm{e}\right)$ was assessed using the EcoInvent database. Table 4 shows the global warming potential for each mortar constituent. Figure 10 presents the global warming potential-to-thermal resistance ratio. The results show that mixtures with similar thermal conductivity performance have a considerably different global warming potential-to-thermal resistance ratio. This parameter is influenced by the percentage of Portland cement. Higher percentages are associated with higher ratios of global warming potential-to-thermal resistance ratios. Even the mixtures containing 


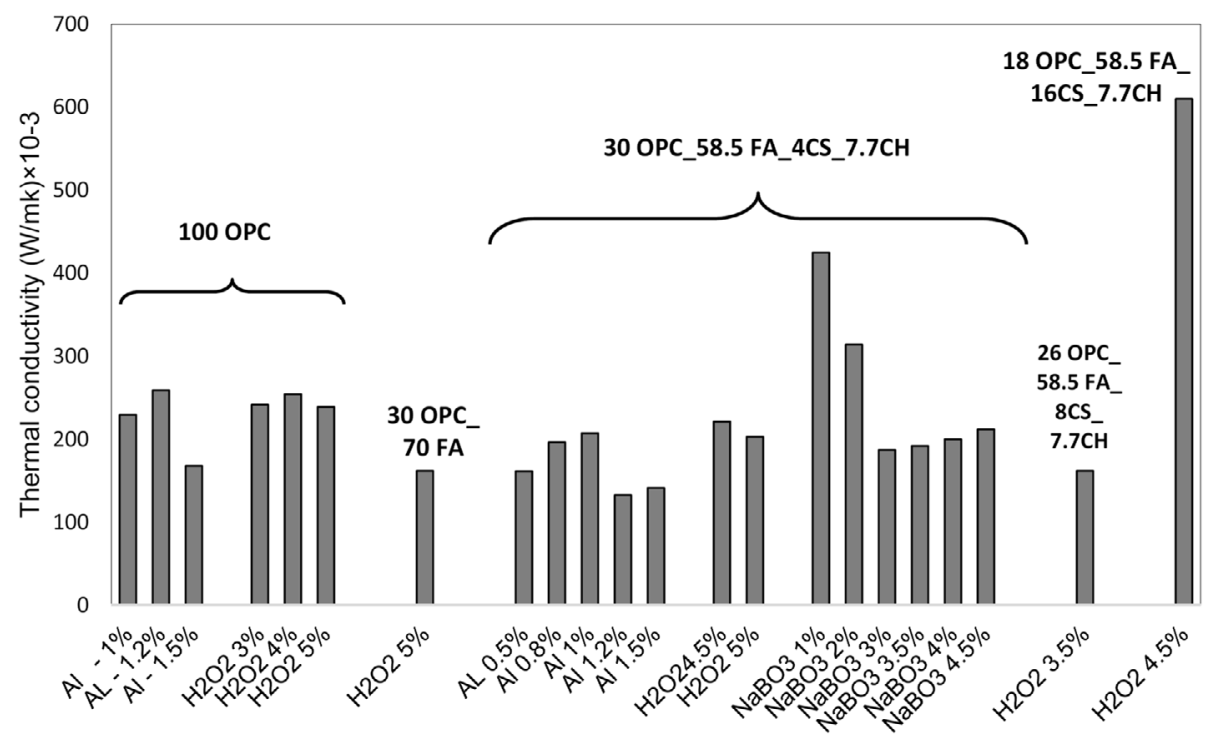

Figure 9. Thermal conductivity.

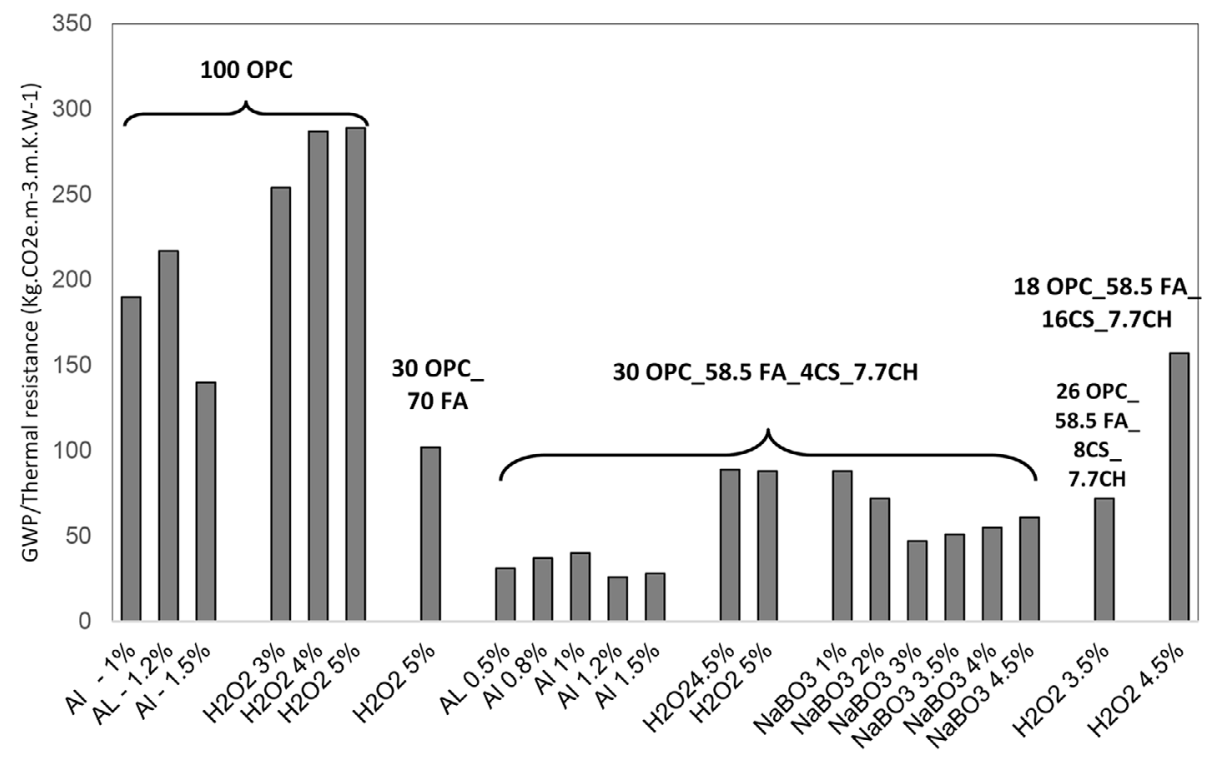

Figure 10. Global warming potential to thermal resistance ratio.

sodium hydroxide have a lower ratio because although the GWP of $\mathrm{NaOH}$ is 2.65 times higher than the GWP of Portland cement, the amount of OPC used in those mixtures is much higher. The mixture $26 \mathrm{OPC}+58.3 \mathrm{FA}+8 \mathrm{CS}+7.7 \mathrm{CH}$ with $3.5 \%$ hydrogen peroxide foaming has a global warming potential of $443 \mathrm{KgCO}_{2 \mathrm{eq}} / \mathrm{m}^{3}$. 
Table 5. Costs of the materials (euro $/ \mathrm{kg}$ ).

\begin{tabular}{lcccccccccc}
\hline Sand & Cement & $\begin{array}{c}\text { Calcium } \\
\text { hydroxide }\end{array}$ & $\begin{array}{c}\mathrm{Fly} \\
\text { ash }\end{array}$ & Kaolin & $\begin{array}{c}\text { Sodium } \\
\text { hydroxide }\end{array}$ & Water & $\mathrm{SP}$ & $\mathrm{H}_{2} \mathrm{O}_{2}$ & $\mathrm{NaBO}_{3}$ & AL \\
\hline .02 & .1 & .3 & .03 & .29 & .85 & .1 & .82 & .98 & 1.5 & 32.4 \\
\hline
\end{tabular}

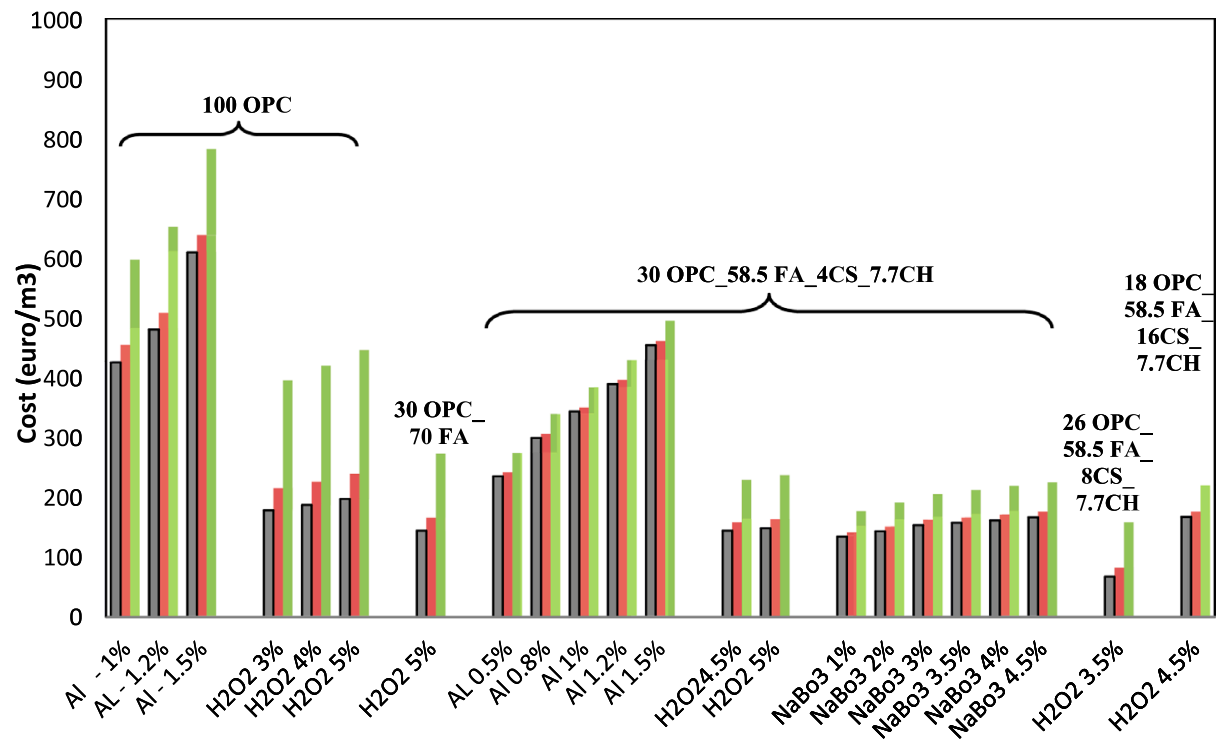

Figure 11. Cost of one-part geopolymer mixtures (Gray bars) Materials cost (Red bars) Materials cost for a carbon cost in scenario 1 (Green bars) Materials cost for a carbon cost in scenario 2 .

\section{Cost analysis}

The cost of materials are listed in Table 5, which shows that the Al powder foaming agent has a much higher cost than the other two foaming agents. The cost of the mixtures is presented in Figure 11. The results show that using Al powder leads to a significant increase of the cost of the alkali-activated mixtures. The most cost-efficient mixtures $\left(67\right.$ euro $\left./ \mathrm{m}^{3}\right)$ were obtained for $26 \mathrm{OPC}+58.3 \mathrm{FA}+8 \mathrm{CS}+7.7 \mathrm{CH}$ with $3.5 \%$ hydrogen peroxide foaming agent. The use of mixtures based on the aluminium powder is not feasible because they are not cost efficient at all. The mixture based on the aluminium powder foaming agent with better economic performance (30 $\mathrm{OPC}+58.3 \mathrm{FA}+4 \mathrm{CS}+7.7 \mathrm{CH}$ ) costs more than $200 \mathrm{euro} / \mathrm{m}^{3}$. This represents more than twice the cost of Ytong masonry blocks $\left(70-80\right.$ euro $\left./ \mathrm{m}^{3}\right)$. It is worth remembering that foam mortars based on classical two-part alkali-activated mortars present a cost above 300 euro $/ \mathrm{m}^{3}$ (Abdollahnejad et al., 2015). Figure 11 also includes cost simulations for two scenarios: (a) Carbon social cost of 34.7 euro/ton as per US study (Stanford Report, 2015); (b) Carbon social cost of 206.3 euro/ton (Moore \& Diaz, 2015). When the cost of the mixtures includes the cost of carbon dioxide emissions mixtures based on hydrogen peroxide, these mixtures show a substantial increase in their cost. A minor increase is noticed in aluminium powder-based mixtures. The results confirm that in both scenarios the mixture $26 \mathrm{OPC}+58.3 \mathrm{FA}+8 \mathrm{CS}+7.7 \mathrm{CH}$ with $3.5 \%$ hydrogen 


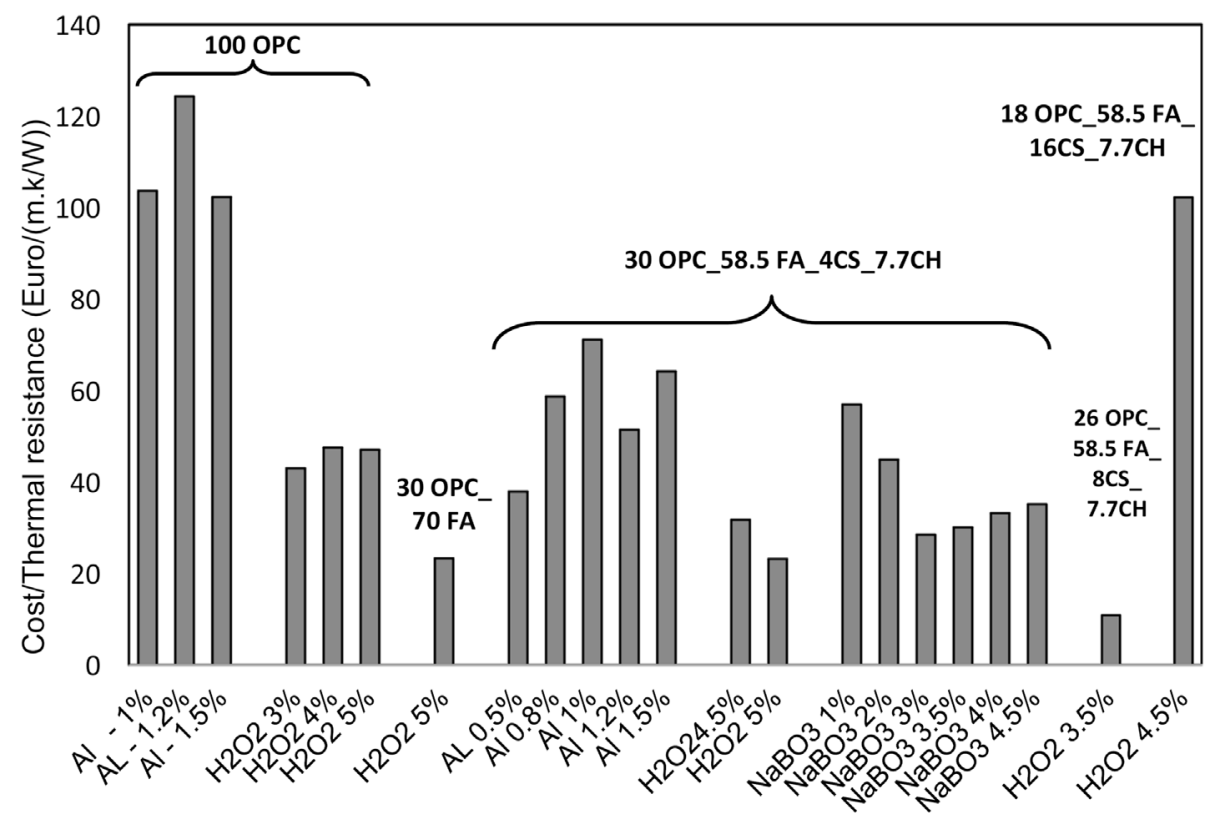

Figure 12. Cost-to-thermal resistance ratio.

peroxide foaming agent is still the most cost efficient. The results of the cost-to-thermal resistance ratio are presented in Figure 12. The best ratio was detected for the mixture $26 \mathrm{OPC}+58.3 \mathrm{FA}+8 \mathrm{CS}+7.7 \mathrm{CH}$ and is around 10 euro/(m K/W).

\section{Conclusions}

Buildings are responsible for more than $40 \%$ of the energy consumption and greenhouse gas emissions. Thus, increasing building energy efficiency is one the most cost-effective ways to reduce emissions. The use of thermal insulation materials could constitute the most effective way of mitigating heat loss in buildings by minimising heat energy needs. The discovery of one-part alkali-activated cements is considered a key event in the evolution of low carbon alkali-activated technology. Although, they are associated with very low compressive strength, they also show the potential to be used in thermal insulation applications. The results show that the use of aluminium powder is very effective in obtaining foam materials with low thermal conductivity.

An increase of bulk density with the rise of aluminium powder content was noticed and can be related to pore collapses. Aluminium powder allows the production of mortar mixtures with a compressive strength of above $6 \mathrm{MPa}$, however, its high cost means they are commercially useless when facing the competition of commercial cellular concrete. The mortar mixture based on aluminium powder mortar with the lowest cost (30 $\mathrm{OPC}+58.3 \mathrm{FA}+4 \mathrm{CS}+7.7 \mathrm{CH})$ costs more than $200 \mathrm{euro} / \mathrm{m}^{3}$. This represents more than twice the cost of Ytong masonry blocks $\left(70-80\right.$ euro $\left./ \mathrm{m}^{3}\right)$. It is worth remembering that foam mortars based on classical two-part alkali-activated mortars have a cost above 300 euro $/ \mathrm{m}^{3}$, which shows that two-part alkali-activated cements are not a cost-effective solution for the production of thermal insulation materials. The mixture $26 \mathrm{OPC}+58.3$ $\mathrm{FA}+8 \mathrm{CS}+7.7 \mathrm{CH}$ with $3.5 \%$ hydrogen peroxide shows an acceptable compressive 
strength and thermal conductivity complying with the requirements for the grades 4 and 5 of the Korean Industrial Standard code for foam concrete for floor heating systems ( $\geq 1.4 \mathrm{MPa}$ and $\leq .16 \mathrm{~W} / \mathrm{m} \mathrm{K}$ ). This mixture is cost efficient $\left(67 \mathrm{euro} / \mathrm{m}^{3}\right)$ and has a low global warming potential of $443 \mathrm{KgCO}_{2 \mathrm{eq}} / \mathrm{m}^{3}$. When the cost of the mixtures includes the cost of carbon dioxide emissions, mixtures based on hydrogen peroxide show a substantial increase in their cost. A minor increase is noticed in aluminium powder-based mixtures. The results confirm that in both carbon dioxide social cost scenarios the mixture $26 \mathrm{OPC}+58.3 \mathrm{FA}+8 \mathrm{CS}+7.7 \mathrm{CH}$ with $3.5 \%$ hydrogen peroxide foaming agent is still the most cost efficient.

\section{Disclosure statement}

No potential conflict of interest was reported by the authors.

\section{References}

Abdollahnejad, Z., Hlavacek, P., Miraldo, S., Pacheco-Torgal, F., \& Aguiar, A. (2014). Compressive strength, microstructure and hydration products of hybrid alkaline cements. Materials Research, 17, 829-837.

Abdollahnejad, Z., Pacheco-Torgal, F., Aguiar, A., \& Jesus, C. (2015). Durability of fly ash-based geopolymer. Key Engineering Materials, 634, 113-120.

Abdollahnejad, Z., Pacheco-Torgal, F., \& Félix, T. (2015). Mix design, properties and cost analysis of fly ash-based geopolymer foam. Construction and Building Materials, 80, 18-30.

Arellano Aguilar, R., Burciaga Díaz, O., \& Escalante García, J. I. (2010). Lightweight concretes of activated metakaolin-fly ash binders, with blast furnace slag aggregates. Construction and Building Materials, 24, 1166-1175.

Damjanovic, A., Genshaw, M. A., \& Bockris, J. O. M. (1967). Hydrogen peroxide formation in oxygen reduction at gold electrodes, Journal of Electroanalytical Chemistry and Interfacial Electrochemistry, 15, 173-180.

Davidovits, J. (1979). Synthesis of new high temperature geo-polymers for reinforced plastics/composites (pp. 151-154). SPE PACTEC 79 Society of Plastic Engineers, Brookfield Center.

Feng, J., Zhang, R., Gong, L., Li, Y., Cao, W., \& Cheng, X. (2015). Development of porous fly ash based geopolymer with low thermal conductivity. Materials and Design, 65, 529-533.

Garcia-Lodeiro, I., Fernández-Jiménez, A., \& Palomo, A. (2013). Alkali-activated based concrete. In F. Pacheco-Torgal, S. Jalali, J. Labrincha \& V. M. John (Eds.), Eco-efficient concrete (pp. 439-487). Cambridge: Woodhead. ISBN 978-0-85709-424-7.

Hlaváček, P., Šmilauer, V., Škvára, F., Kopecký, L., \& Šulc, R. (2015). Inorganic foams made from alkali-activated fly ash: Mechanical, chemical and physical properties. Journal of the European Ceramic Society, 35, 703-709.

Ke, X., Bernal, S., Ye, N., Provis, J., \& Yang, J. (2015). One-part geopolymers based on thermally treated red Mud/NaOH blends. Journal of the American Ceramic Society, 98, 5-11.

Koloušek, D., Brus, J., Urbanova, M., Andertova, J., Hulinsky, V., \& Vorel, J. (2007). Preparation, structure and hydrothermal stability of alternative (sodium silicate-free) geopolymers. Journal of Materials Science, 42, 9267-9275.

Macphee, D. E. (1989). Solubility and aging of calcium silicate hydrates in alkaline solutions at $25^{\circ} \mathrm{C}$. Journal of the American Ceramic Society, 72, 646-654.

Masi, G., Rickard, W., Vickers, 1., Bignozzi, M., \& van Riessen, A. (2014). A comparison between different foaming methods for the synthesis of light weight geopolymers. Ceramics International, 40, 13891-13902.

Moore, F., \& Diaz, D. (2015). Temperature impacts on economic growth warrant stringent mitigation policy. Nature Climate Change, 5, 127-131.

NP EN 450-1. (2012). Fly ash for concrete - Part 1: Definition, specifications and conformity criteria.

OECD. (2003). Environmental sustainable building - Challenges and policies. Paris. 
Pacheco-Torgal, F. (2014). Eco-efficient construction and building materials research under the EU Framework Programme Horizon 2020. Construction and Building Materials, 51, 151-162.

Pacheco-Torgal, F., \& Jalali, S. (2011). Eco-efficient construction and building materials. London: Springer Verlag.

Pacheco-Torgal, F., Abdollahnejad, Z., Camões, A., Jamshidi, M., \& Ding, Y. (2012). Durability of alkali-activated binders. A clear advantage over Portland cement or an unproven issue? Construction and Building Materials, 30, 400-405.

Pacheco-Torgal, F., Cabeza, L., Mistretta, M., Kaklauskas, A., \& Granqvist, G. (2013). Nearly zero energy building refurbishment. A multidisciplinary approach. London: Springer Verlag.

Pacheco-Torgal, F., Jalali, S., \& Fucic, A. (2012). Toxicity of building materials. Cambridge: Woodhead.

Pacheco-Torgal, F., Labrincha, J. A., Leonelli, C., Palomo, A., \& Chindaprasirt, P. (2014). Handbook of alkali-activated cements, mortars and concretes (1st ed.). Cambridge: WoodHead - Elsevier Science and Technology

Peng, M.-X., Wan, Z.-H., Shen, S. H., \& Xiao, Q. G. (2014). Synthesis, characterization and mechanisms of one-part geopolymeric cement by calcining low-quality kaolin with alkali. Materials and Structures, 48, 699-708.

Provis, J. L. (2013). Durability of geopolymers as 21st century concretes. ERC Starting grant for the period 2013-2018. https://erc.europa.eu/durability-geopolymers-21st-century-concretes (accessed on 10 of September)

Provis, J. L., \& Van Deventer, J. S. J. (2009). Geopolymers: Structure, processing, properties and industrial applications. Cambridge: Woodhead.

Regulation (EU) 305, Construction Products Regulation (2011).

Sanjayan, J., Nazari, A., Chen, L., \& Nguyen, G. (2015). Physical and mechanical properties of lightweight aerated geopolymer. Construction and Building Materials, 79, 236-244.

Stanford Report. (2015). Estimated social cost of climate change not accurate, Stanford scientists say. Retrieved from http://news.stanford.edu/news/2015/january/emissions-social-costs-011215. html

UN. (2010). Energy for a sustainable future. The Secretary-General's Advisory Group on energy and climate change. United Nations: New York, NY.

Van Deventer, J., Provis, J., \& Duxson, P. (2012). Technical and commercial progress in the adoption of geopolymer cement. Minerals Engineering, 29, 89-104.

WHO. (2014). Urban population growth. Global health observatory. http://www.who.int/gho/ur ban health/situation trends/urban population growth text/en/ (Accessed on 2 of October)

Yang, K.-H., \& Lee, K.-H. (2013). Tests on alkali-activated slag foamed concrete with various water-binder ratios and substitution levels of fly ash. Journal of Building Construction and Planning Research, 1, 8-14.

Yang, K.-H., Lee, K.-H., Song, J.-K., \& Gong, M.-H. (2014). Properties and sustainability of alkali-activated slag foamed concrete. Journal of Cleaner Production, 68, 226-233.

Zhang, Z., Provis, J., Reid, A., \& Wang, H. (2014). Geopolymer foam concrete: An emerging material for sustainable construction. Construction and Building Materials, 56, 113-127.

Zheng, D., Van Deventer, J. S. L., \& Duxson, P. (2007). The dry mix cement composition, methods and systems involving same. International Patent WO 2007/109862 A1. http://www.goo gle.com/patents/WO2007109862A1?cl=en (Accessed on 29 of September) 